\title{
Identification and Analysis of the Main Affecting Factors of Transmission and Transformation Project Cost
}

\author{
Dongni Wei
}

\begin{abstract}
Based on the key factors that can influence the investment control of power transmission and transformation project, this study reasonable utilize the factor contribution analysis methods of ranking, grey correlation degree, nonparametric variance test to analyze different main factors that can influence the cost, such as itemized expenses, technical conditions, natural factors.
\end{abstract}

Index Terms - Transmission and transformation project, cost, factor identification and analysis.

\section{INTRODUCTION}

Power transmission and transformation project has the features of long construction period, huge investment and complex technology composition. Compared with the specific project, investment of these projects affected by technical conditions, and macroeconomic aspects of natural factors, present certain volatility and regularity.

According to the affecting mechanism of different factors, we can study the combining site of different analysis methods and actual situation, in order to analyze the main influencing factors. Rank all the influencing factors by the influencing degree and provide reliable theoretical basis and analysis method for cost control work, so that we can control investment effectively.

\section{Cost Impact Factor Analysis Method And The CHOICE}

According to the nature of the main influence factors and characteristics of data analysis method is as follows:

\section{A. Use the Grey Correlation Degree Method to Identify and Analysis the Technological Factors}

Since the amount of power transmission and transformation engineering samples is uncertain, so we need to priority choose the analysis method that is not affected by the amount. Grey correlation method does not need too many data and it is based on the analysis of the correlation coefficient. This method measure the correlation degree between factors according to the development trend of similar or dissimilar degree [1]-[3]. Due to technical indexes and economic indexes does not have the same dimension, gray correlation analysis can remove the influence of the dimension and calculate the relation degree among factors in the gray system

Manuscript received June 1, 2016; revised December 16, 2016.

Dongni Wei is with Economic and Technical Research Institute of Ningxia Electric Power Corporation, China (e-mail: smhmagic_007@126.com). correlation factor concentration. Considering the grey correlation model is not limited to the sample size, this method is superior to the classical mathematical methods to describe the dynamic process. It is applicable to study the correlation of the main technical conditions for the economic performance of enterprise [4]-[8].

\section{B. Calculate the Contribution Degree to Identify and Analysis the Price Factor [9]-[11]}

Static investment cost of power transmission and transformation project is mainly made up of a number of project cost, such as power transformation engineering cost, installation cost, equipment cost and other cost. When calculating the contribution degree of each cost to the static investment change rate, we need to consider the proportion that the cost components itself accounts for static investment and the normal change rate of cost components itself. So, the contribution degree method is used to calculate more effectively and clearly [12], [13] (Fig. 1).

\section{Adopt the Method of Nonparametric Test to Identify and Analysis the Natural Environment Factors}

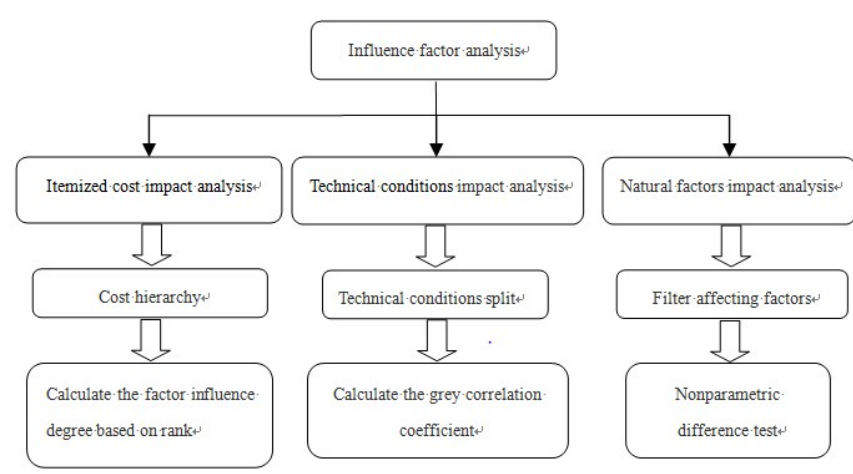

Fig. 1. Roadmap of factor analysis.

\section{THE MAIN INFLUENCE FACTOR IDENTIFICATION AND ANALYSIS OF SUBSTATION PROJECT}

\section{A. Sample Situation}

TABLE I: SAmple TABLE of 110 Kv NeW-Built Substation ProjeCt

\begin{tabular}{|c|c|c|c|c|c|}
\hline \multicolumn{3}{|c|}{ technical project } & \multirow[b]{2}{*}{$\begin{array}{c}\text { number of } \\
\text { project }\end{array}$} & \multirow[b]{2}{*}{$\begin{array}{l}\text { Capacity of the } \\
\text { scale (MVA) }\end{array}$} & \multirow[b]{2}{*}{$\begin{array}{l}\text { static investment(ten } \\
\text { thousand yuan) }\end{array}$} \\
\hline substation type & $\begin{array}{c}\text { High side } \\
\text { power- } \\
\text { distribution } \\
\text { device type }\end{array}$ & $\begin{array}{c}\text { number of main } \\
\text { transformer } \times \text {. } \\
\text { single capacity } \\
\text { (MVA) }\end{array}$ & & & \\
\hline \multirow{4}{*}{ Outdoors } & \multirow{4}{*}{ GIS } & $1 / 3 \times 50$ & 6 & 300 & $14,497.87$ \\
\hline & & $2 / 3 \times 50$ & $3+$ & 300 & $10,686.15$ \\
\hline & & $2 / 3 \times 63$ & 1 & 126 & $3,237.94$ \\
\hline & & $1 / 2 \times 63$ & 1 & 63 & $2,341.70$ \\
\hline \multicolumn{3}{|c|}{ Total } & 11 & 789 & $30,763.66$ \\
\hline
\end{tabular}


Taking the $110 \mathrm{kV}$ new-built substation project of $x \times$ Company as an example, basic situation of the samples is as follow Table I.

\section{B. Itemized Expenses Analysis Based on the Rank of Factor Contribution}

- Cost hierarchy

We can make division of the cost hierarchies according to the substation project item cost containment relationship, and the main components of the static investment cost include project construction cost, equipment purchase cost, installation cost, and other cost. These four subentries should be the emphasis when doing the analysis of their contribution to the cost.

- Factor contribution analysis based on the rank

TABLE II: TABLE OF CONTRIBUTION THE CONSTITUENT ELEMENTS TO StATIC InVESTMENT ANALYSIS OF THE 110 KV NEW SubSTATION PROJECT

\begin{tabular}{|c|c|c|c|c|c|}
\hline \multirow[b]{2}{*}{ Cost component factors } & \multicolumn{2}{|c|}{ Cost of the unit capacity } & \multicolumn{2}{|c|}{ Cost rate of the unit capacity } & \multirow{2}{*}{$\begin{array}{c}\text { contribution } \\
\text { degree } \\
(\mathrm{Z} 1 \times \mathrm{Z} 2)\end{array}$} \\
\hline & $\begin{array}{c}\text { Cost } \\
\text { (Yuan } / \mathrm{kVA})\end{array}$ & $\mathrm{Z1}$ & Change rate $(\%)$ & $\mathrm{Z} 2$ & \\
\hline construction cost & 91.38 & 3 & -4.204 & -1 & -3 \\
\hline equipment cost & 191.86 & 4 & 9.50 & 2 & 8 \\
\hline installation cost & 54.65 & 1 & 10.03 & -3 & -3 \\
\hline other cost & 51.15 & 2 & 29.76 & -4 & -8 \\
\hline static investment & \multicolumn{2}{|c|}{389.91} & \multicolumn{2}{|l|}{-3.53} & דיה \\
\hline
\end{tabular}

The Table II shows that static investment in 2014 decreased by $3.53 \%$ compared to 2013 . It is other cost that make the most contribution to the decline of the static investment, followed by installation construction cost and project construction cost. Equipment purchase expense rose slightly in 2014 , but since the rising proportion is low, the static investment kept fall in 2014.

- Technical condition analysis based on the grey correlation

According to the principle of the main technical condition, there are 6 main factors that influence the project static investment of the $110 \mathrm{kV}$ new-built substation project: substation capacity, master complex building area, site earthwork quantity, high voltage wire count, medium voltage wire count, and low voltage wire count.

TABLE III: GREY CORRELATION COEFFICIENT MATRIX OF $110 \mathrm{KV}$ NEW
\begin{tabular}{|c|c|c|c|}
\hline $\begin{array}{r}\text { influence } \\
\text { factors }\end{array}$ & $\begin{array}{c}\text { substation } \\
\text { capacity }\end{array}$ & $\begin{array}{c}\text { master complex } \\
\text { building area }\end{array}$ & $\begin{array}{c}\text { site earthwork } \\
\text { quantity }\end{array}$ \\
\hline $\begin{array}{c}\text { correlation } \\
\text { coefficient }\end{array}$ & 0.848 & 0.836 & 0.683 \\
\hline $\begin{array}{r}\text { influence } \\
\text { factors }\end{array}$ & $\begin{array}{c}\text { high voltage } \\
\text { wire count }\end{array}$ & $\begin{array}{c}\text { medium voltage } \\
\text { wire count }\end{array}$ & $\begin{array}{c}\text { low voltage } \\
\text { wire count }\end{array}$ \\
\hline $\begin{array}{c}\text { correlation } \\
\text { coefficient }\end{array}$ & 0.856 & 0.687 & 0.787 \\
\hline
\end{tabular}

The Table III shows that the high voltage wire count has the greatest influence on the project static investment, and the correlation coefficient is 0.856 . The rank of main technical conditions according to the influence on the static investment is high voltage wire count, substation capacity, master complex building area, low voltage wire count, medium voltage wire count, and site earthwork quantity.
- Analysis of the natural factors based on nonparametric test

There are 6 kinds of landform in the 11 samples of $110 \mathrm{kV}$ new substation project, including depression/concave ground, down land, slope, high ground, mountainous region, ponds/ditches. There are 5 levels of soil bearing capacity: 95,100,110,120,130. According to calculation, the effects of two variables on static investment are both insignificant, and comparatively speaking, topography of the $110 \mathrm{kV}$ new-built substation project has greater influence than the soil bearing capacity.

\section{THE MAIN INFLUENCE FACTOR IDENTIFICATION AND ANALYSIS OF ROUTE PROJECT}

\section{A. Sample Situation}

Taking the $110 \mathrm{kV}$ route project of $\times \times$ Company as an example, basic situation of the sample is as Table IV:

TABLE IV: SAMPLE TABLE OF $110 \mathrm{KV}$ Route PROJECT

\begin{tabular}{|c|c|c|c|c|c|c|c|}
\hline \multicolumn{2}{|c|}{ technical proposal } & \multicolumn{2}{|c|}{ project amount } & \multicolumn{2}{|c|}{$\begin{array}{l}\text { single circuit length } \\
(\mathrm{km})\end{array}$} & \multicolumn{2}{|c|}{ static investment(Yuan) } \\
\hline $\begin{array}{l}\text { circuit } \\
\text { number }\end{array}$ & $\begin{array}{c}\text { cross-section } \\
\text { of conductor } \\
\left(\mathrm{mm}^{2}\right)\end{array}$ & amount & proportion & length & proportion & $\begin{array}{l}\text { amount of } \\
\text { money }\end{array}$ & proportion \\
\hline \multirow{2}{*}{ single } & 300 & 2 & 9.09 & 4.77 & 1.26 & 499.28 & 1.79 \\
\hline & 400 & 2 & 9.09 & 8.72 & 2.30 & 690.40 & 2.48 \\
\hline \multirow{2}{*}{ double } & 300 & 2 & 9.09 & 9.46 & 2.50 & 667.00 & 2.40 \\
\hline & 400 & 6 & 27.27 & 163.19 & 43.11 & $9,901.81$ & 35.60 \\
\hline \multirow{3}{*}{ single+double } & 240 & 1 & 4.55 & 25.00 & 6.60 & $2,444.24$ & 8.79 \\
\hline & 300 & 7 & 31.82 & 133.47 & 35.26 & $9,580.02$ & 34.44 \\
\hline & 400 & 2 & 9.09 & 33.90 & 8.96 & $4,033.19$ & 14.50 \\
\hline \multicolumn{2}{|c|}{ Totle } & 22 & 100 & 378.51 & 100 & $27,815.94$ & 100 \\
\hline
\end{tabular}

\section{B. Itemized Expenses Analysis Based On The Rank Of Factor Contribution}

- Cost hierarchy

TABLE V: TABLE OF CONTRIBUTION THE CONSTITUENT ELEMENTS TO StATIC INVESTMENT ANALYSIS OF THE $110 \mathrm{KV}$ RouTE PROJECT

\begin{tabular}{|c|c|c|}
\hline first level & second level & third level \\
\hline Ontology cost & . & . \\
\hline Auxiliary facilities cost & 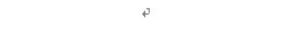 & . \\
\hline \multirow{7}{*}{ other cost } & \multirow{5}{*}{$\begin{array}{l}\text { The cost of construction site requisition } \\
\text { and cleaning }\end{array}$} & $\begin{array}{l}\text { Permanent land occupation } \\
\text { cost for tower footing }\end{array}$ \\
\hline & & Green compensate cost \\
\hline & & compensate cost for trees cut down \\
\hline & & Housing demolition compensation cost \\
\hline & & $\begin{array}{l}\text { Large factories demolition compensation } \\
\text { and other large damages compensation }\end{array}$ \\
\hline & The cost of the project early stage work & . \\
\hline & Other special cost & a \\
\hline
\end{tabular}

- Factor contribution analysis based on the rank

The calculation and result of the contribution degree that first level itemized expenses of route project to the change of the cost per capacity length can be seen in the Table VI.

The Table VI shows that every first level cost promotes the rise of cost per capacity length. Among them, the other cost does the greatest contribution. Considering the cost proportion and growth rate, other cost has the greatest influence to the cost per capacity length. 
TABLE VI: THE CONTRIBUtion Degree of THE ROUTE ProjeCt FirST LeVel Itemized EXPenses to the Change OF the Cost Per CAPACITY

\begin{tabular}{|c|c|c|c|c|}
\hline \multicolumn{5}{|c|}{ LENGTH } \\
\hline \multirow{2}{*}{$\begin{array}{l}\text { itemized } \\
\text { expenses }\end{array}$} & \multicolumn{4}{|c|}{ cost per capacity length } \\
\hline & \multicolumn{3}{|c|}{ cost $($ Yuan $/ \mathrm{kVA} \cdot \mathrm{km})$} & $\mathrm{Z} 1$ \\
\hline Ontology cost & \multicolumn{3}{|c|}{7.62} & 3 \\
\hline $\begin{array}{c}\text { Auxiliary } \\
\text { facilities cost }\end{array}$ & \multicolumn{3}{|c|}{0.038} & 1 \\
\hline other cost & \multicolumn{3}{|c|}{1.88} & 2 \\
\hline Total & \multicolumn{4}{|c|}{9.53} \\
\hline \multicolumn{3}{|c|}{ change rate of cost per capacity length } & \multirow{2}{*}{\multicolumn{2}{|c|}{$\begin{array}{c}\text { contribution } \\
\text { degree } \\
(\mathrm{Z} 1 \times \mathrm{Z} 2) \\
\end{array}$}} \\
\hline change rate & $(\%)$ & $\mathrm{Z} 2$ & & \\
\hline \multicolumn{2}{|c|}{9.93} & 1 & & 3 \\
\hline \multicolumn{2}{|c|}{146.76} & 3 & & 3 \\
\hline \multicolumn{2}{|c|}{37.52} & 2 & & 4 \\
\hline \multicolumn{3}{|c|}{14.71} & & דـ- \\
\hline
\end{tabular}

The calculation and result of contribution degree that the third level cost to per building site cost can be seen in the Table VII. In 2013, 110kV route project does not have large factories demolition compensation and other large damages compensation, so their growth rate is $+\infty$.

TABLE VII: The CONTRIBUtion DegReE of Transmission Line ProJeCt THIRD LEVEL ITEMIZED EXPENSES ON PER BUILDING SITE COST

\begin{tabular}{|c|c|c|c|c|}
\hline \multirow{2}{*}{$\begin{array}{l}\text { itemized } \\
\text { expenses }\end{array}$} & \multicolumn{4}{|c|}{ cost per kilometer } \\
\hline & \multicolumn{3}{|c|}{ cost (ten thousand Yuan $/ \mathrm{km})$} & $\mathrm{Zl}$ \\
\hline $\begin{array}{l}\text { land occupation } \\
\text { of tower footing }\end{array}$ & \multicolumn{3}{|c|}{4.69} & 4 \\
\hline \begin{tabular}{|c|} 
Green \\
compensate cost \\
\end{tabular} & \multicolumn{3}{|c|}{4.69} & 5 \\
\hline timber cutting & \multicolumn{3}{|c|}{2.26} & 3 \\
\hline $\begin{array}{c}\text { housing } \\
\text { demolition }\end{array}$ & \multicolumn{3}{|c|}{0.34} & 1 \\
\hline $\begin{array}{l}\text { Factories } \\
\text { demolition }\end{array}$ & \multicolumn{3}{|c|}{0.56} & 2 \\
\hline $\begin{array}{l}\text { Building the } \\
\text { field }\end{array}$ & \multicolumn{4}{|c|}{13.37} \\
\hline \multicolumn{3}{|c|}{ change rate of per kilometers cost } & \multirow{2}{*}{\multicolumn{2}{|c|}{$\begin{array}{c}\text { contribution } \\
\text { rate } \\
(\mathrm{Z} 1 \times \mathrm{Z} 2)\end{array}$}} \\
\hline change rate & $(\%)$ & $\mathrm{Z} 2$ & & \\
\hline \multicolumn{2}{|c|}{8.77} & 1 & \multicolumn{2}{|r|}{4} \\
\hline \multicolumn{2}{|c|}{59.69} & 3 & \multicolumn{2}{|r|}{15} \\
\hline \multicolumn{2}{|c|}{316.75} & 4 & & 12 \\
\hline \multicolumn{2}{|c|}{-30.11} & -2 & & -2 \\
\hline \multicolumn{2}{|c|}{$+\infty$} & 5 & & 10 \\
\hline \multicolumn{3}{|c|}{53.18} & & -4 \\
\hline
\end{tabular}

The table above shows that green compensate cost of transmission line project has the greatest contribution to per building site cost. This means that walk path choice and local policy of the transmission line project have great influence on per building site cost.

- Technical condition analysis based on the grey correlation According to the principle of the main technical condition, the project static investment of the route project can be divided into 6 main influence factors: route length, wire amount, tower material amount, concrete foundation amount, earthwork volume, and fundamental steel.

TABLE VIII: GREY CORRELATION COEFFICIENT MATRIX OF $110 \mathrm{KV}$ TRANSMISSION LINE PROJECT

\begin{tabular}{|c|c|c|c|}
\hline $\begin{array}{c}\text { influence } \\
\text { factors }\end{array}$ & routelength & $\begin{array}{c}\text { wire } \\
\text { amount }\end{array}$ & $\begin{array}{c}\text { tower } \\
\text { material } \\
\text { amount }\end{array}$ \\
\hline $\begin{array}{c}\text { correlation } \\
\text { coefficient }\end{array}$ & 0.855 & 0.856 & 0.845 \\
\hline $\begin{array}{c}\text { influence } \\
\text { factors }\end{array}$ & $\begin{array}{c}\text { concrete } \\
\text { foundation } \\
\text { amount }\end{array}$ & $\begin{array}{c}\text { volume } \\
\text { volthwork }\end{array}$ & $\begin{array}{c}\text { fundamental } \\
\text { steel }\end{array}$ \\
\hline $\begin{array}{c}\text { correlation } \\
\text { coefficient }\end{array}$ & 0.868 & 0.847 & 0.843 \\
\hline
\end{tabular}

The Table VIII above shows that concrete foundation amount does the greatest influence on cost of the $110 \mathrm{kV}$ transmission line project and the correlation coefficient is 0.868 . The rank of main technical conditions according to the influence on the static investment is concrete foundation amount, wire amount, route length, earthwork volume, tower material amount, and fundamental steel.

- Analysis of the natural factors based on nonparametric test

There are 4 natural factors in the samples of $110 \mathrm{kV}$ transmission line project, including radial thickness of ice, design wind speed, the distribution of topography (Terrain accounted for more than $50 \%$ as the main terrain), and geological conditions.

TABLE IX: Differences Test Analysis Table of The Route Project COST PER CAPACITY LENGTH

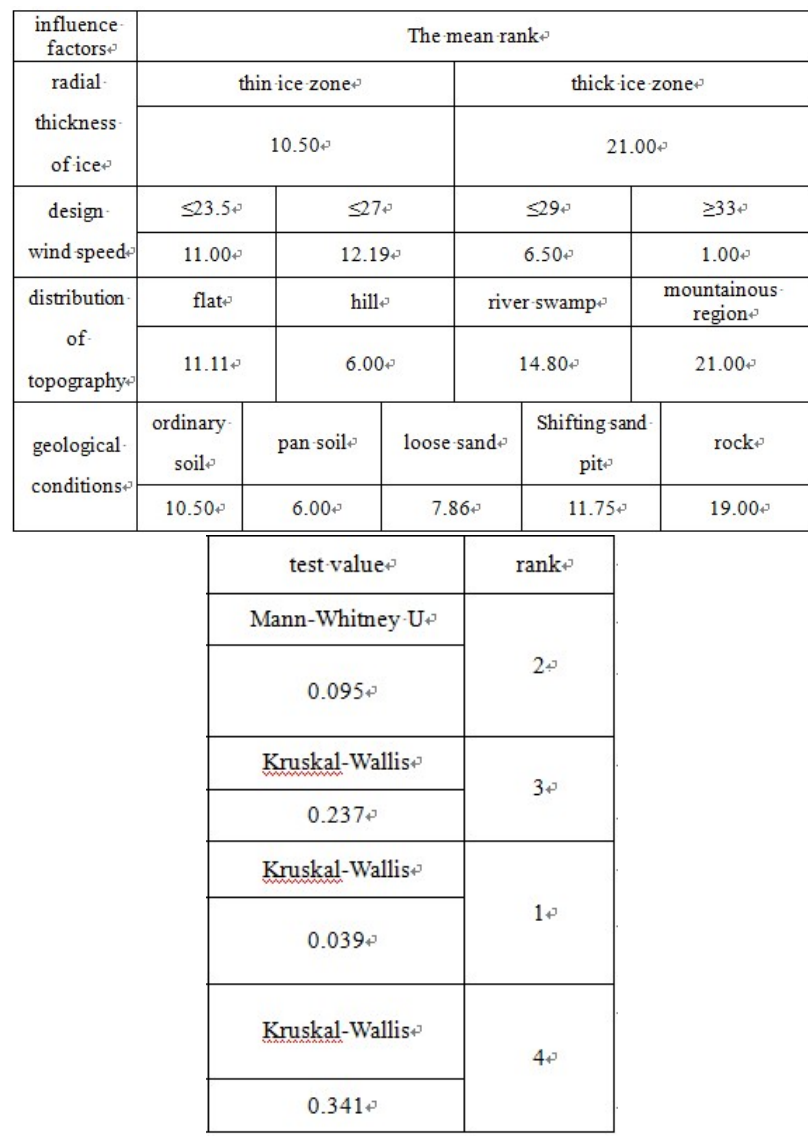


The Table IX shows that the rank of main technical conditions according to the influence on the static investment is distribution of topography, radial thickness of ice, design wind speed, and geological conditions.

\section{CONCLUSION}

According to the different characteristics of the factors that influence the power transmission and transmission line project cost, this paper studies the different factors in classification. For cost, technology, natural these three types of influencing factors, we choose different methods to do the analyses, in order to improve the scientific nature and reliability of the conclusion. With the conclusion we can provide scientific basis of reasonable control for the power engineering construction units and engineering. We can also focus on control of the elements in the process of cost management, in order to make cost under reliable control.

\section{REFERENCES}

[1] W. K. Chan and T. K. L. Tong, "Multi-criteria material selections and end-of-life product strategy: Grey relational analysis approach," Materials \& Design, vol. 28, no. 5, pp. 1539-1546, May 2007.

[2] Y. Luo and Y.-L. Li, "Transmission planning scheme integrated decision-making based on entropy weight and grey relational analysis method," Power System Technology, no. 1, pp. 77-81, 2013.

[3] S.-F. Liu, H. Cai, and Y. Cao, "Research progress on grey relational analysis model," System Engineering Theory and Practice, no. 8, pp. 2041-2046, 2013.

[4] X. L. Zhang et al., "Influence factors analysis of the fan MPPT control based on the grey correlation," Power System Technology, vol. 39, no. 2, pp. 445-449, January 2015.

[5] Y. B. Li, X. Y. Yu, and Z. J. Wang, "Photovoltaic power generation project risk assessment study using the grey correlation degree and TOPSIS method," Power System Technology, vol. 37, no. 6, pp. 1514-1519, June 2013.
[6] H. Z. Nie et al., "Comprehensive decision-making of alternative transmission network planning based on principal component analysis," Power System Technology, vol. 34, no. 6, pp. 134-138, 2010.

[7] J.-P. Zhou et al., "Comprehensive decision-making of transmission network planning based on AHP-GRA," Power System and Clean Energy, vol. 27, no. 9, pp. 66-70, 2011.

[8] X.-H. Li et al., "The research on the evaluation system for existing network based on analytic hierarchy process and Delphi method," Power System Protection and Control, vol. 36, no. 14, pp. 57-61, 2008.

[9] H. H. Harman, Modern Factor Analysis, University of Chicago Press, pp. 175-176, 1976.

[10] H. Liu, "Factor analysis of rural residents' income varies the regional difference in China," Journal of Geographical Sciences, vol. 63, no. 8, pp. 799-806, August 2008.

[11] G. Cuirong et al., "Bank competitiveness evaluation research in China based on factor analysis of listed commercial," Management World, no. 1, pp. 176-177, January 2012.

[12] G. W. Corder and D. I. Foreman, Nonparametric Statistics: A Step-by-Step Approach, Wiley, pp. 1-10, 2014

[13] L. B. Yang et al., "Statistical analysis and quantitative analysis of the law of the urban sewage treatment plant energy consumption," Water Supply and Drainage, vol. 34, no. 10, pp. 42-45, October 2008.

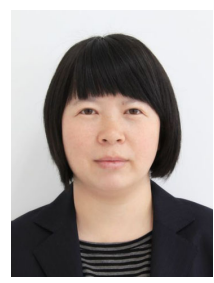

Dongni Wei was born in Yinchuan, Ningxia, China, on November 13, 1975. She received her bachelor of management engineering degree from North China Electric Power University, 1999. In 1999-2011, she worked in Ningxia Power Transmission and Transformation Engineering Company, China. Since 2012 till now, she works in Economic and Technical Research Institute of Ningxia Electric Power Corporation. Some of her previous publications are: "Discussion on establishment of Electric Power Construction Enterprise's quota," Goods and Quality: Construction and Development, pp. 189-190, November 2011; "How to effectively control construction cost on the electric power engineering project design and review period," Northwest Electric Power Construction, pp. 1-3, May 2014. 